3. William J. Petersen, Iowa History Reference Guide. State Historical Society of Iowa. Iowa City. 1952

4. The History of Henry County, lowa. Western Historical Society. Chicago. 1879

5. Historical Sketch and Alumni Record of Iowa Wesleyan University. Mt. Pleasant. 1905

6. Historical Sketch and Alumni Record of Iowa Wesleyan College. Mt. Pleasant. 1917

7. Charles J. Kennedy, History and Alumni Record of Iowa Wesleyan College. 1842-1942. Mt. Pleasant. 1942

8. Katalog des Deutschen Kollegiums. 1873-1880. Mt. Pleasant

9. Catalogs of Iowa Wesleyan University, 1873-1910

10. E. C. Magaret, Friedrich Mung and George B. Addicks, Jubilaumsbuch der St. Louis Deutschen Konferenz. Jennings and Graham. Cincinnati. 1905

11. Mt. Pleasant Weekly News. 1908-1909

12. The Croaker of Iowa Wesleyan University, 1906, 1909, 1910

13. St. Louis German Conference 1879-1925. St. Louis 1925

14. St. Louis German Conference. Official Minutes. 1924

\title{
First Threshing Machine in Woodbury County
}

FROM SMITHLAND.-Last Monday a threshing machine arrived at the farm of O. B. Smith, and commenced threshing, being the first work of the kind in Woodbury County. O. B.'s farm was the first that raised wheat in the County, and the first to have a machine on it. - The farm was worked this season by Abel Smith and James Moon, and they raised over six hundred bushels of small grain-wheat, oats and rye. The rye yielded 35 bushels to the acre; oats 45 ; wheat 21 . We hailed the arrival of the machine with joy. The Smithland boys got up a dance, and things went off after the old sort down East. The machine is from Davenport, and belongs to $\mathrm{Mr}$. Treps, a brother-in-law of Benj. Stafford of the Floyd. It is an excellent one.

November 29, 1859.-Sioux City Register, December 3, 1959. 
Copyright of Annals of Iowa is the property of State of Iowa, by \& through the State Historical Society of Iowa and its content may not be copied or emailed to multiple sites or posted to a listserv without the copyright holder's express written permission. However, users may print, download, or email articles for individual use. 